\title{
Characteristics of atmospheric trace gases, particulate matter, and heavy metal pollution in Dhaka, Bangladesh
}

\author{
Abdus Salam • Tofazzal Hossain • M. N. A. Siddique • \\ A. M. Shafiqul Alam
}

Received: 7 July 2008 / Accepted: 5 September 2008/Published online: 27 September 2008

(C) The Author(s) 2008. This article is published with open access at Springerlink.com

\begin{abstract}
Aerosol particulate matter $\left(\mathrm{PM}_{10}\right.$ and $\left.\mathrm{PM}_{2.5}\right)$ and trace gases $\left(\mathrm{SO}_{2}, \mathrm{NO}_{2}, \mathrm{CO}\right.$ and $\left.\mathrm{O}_{3}\right)$ were sampled at five locations in greater Dhaka, Bangladesh, between January and April 2006. Particulate matter was collected on microfiber filters with a low-volume sampler, and trace gases $\left(\mathrm{SO}_{2}, \mathrm{NO}_{2}\right.$, and $\left.\mathrm{O}_{3}\right)$ were collected with an impinger equipped with PM samplers. Carbon monoxide was determined using the Indicator Tube method. The total average concentrations of $\mathrm{SO}_{2}, \mathrm{NO}_{2}, \mathrm{CO}$, and $\mathrm{O}_{3}$ were $48.3,21.0,166.0$ and $28 \mu \mathrm{g} \mathrm{m}^{-3}$, respectively. The total average concentrations of $\mathrm{SO}_{2}$ and $\mathrm{NO}_{2}$ were much lower than the annual average guideline values of the World Health Organization (WHO). The total average $\mathrm{O}_{3}$ concentration was also much lower than the daily maximum values established by WHO (average of $100 \mu \mathrm{g} \mathrm{m}^{-3}$ for an 8-h sample). The total average concentrations of five sites were 263, 75.5 and $66.2 \mu \mathrm{g} \mathrm{m}^{-3}$ for SPM, $\mathrm{PM}_{10}$ and $\mathrm{PM}_{2.5}$, respectively. The mass of $\mathrm{PM}_{2.5}$ is approximately $88 \%$ of the $\mathrm{PM}_{10}$ mass, indicating that fossil fuel is the main source of PM in Dhaka. An atomic absorption spectrophotometer was used to determine the heavy metal concentrations in the $\mathrm{PM}_{2.5}$ size fraction. The total average concentrations of As, $\mathrm{Cd}, \mathrm{Cu}, \mathrm{Fe}, \mathrm{Pb}$, and $\mathrm{Zn}$ in $\mathrm{PM}_{2.5}$ were $6.3,13,94,433,204$, and $381 \mathrm{ng} \mathrm{m}^{-3}$, respectively. The $\mathrm{Pb}$ concentration in Dhaka shows a decreasing tendency, presumably due to the ban on the use of leaded fuel. The overall trace metal concentrations in Dhaka are higher than those in European (e.g., Spain, Norway) and East Asian (e.g., Taiwan) locations, but lower than those measured in Southeast
\end{abstract}

A. Salam $(\triangle) \cdot$ T. Hossain $\cdot$ M. N. A. Siddique $\cdot$ A. M. S. Alam Department of Chemistry, Faculty of Science,

University of Dhaka,

Dhaka 1000, Bangladesh

e-mail: asalam@gmail.com
Asian (Kanpur, Delhi, Mumbai, India; Lahore, Pakistan) cities.

Keywords Air pollution - Heavy metals · Particulate matter . Trace gases

\section{Introduction}

Air pollution has a great impact on human health, climate change, agriculture, and the natural ecosystem (Decker et al. 2000; Mayer et al. 2000; Molina and Molina 2004; Molina et al. 2004). The modernization and industrialization of developing countries has led to the increased use of fossil fuels and their derivatives. As such, developing countries are confronted with the great challenge of controlling the atmospheric pollution, especially in the rapidly growing megacities. Concern about air pollution in urban regions is receiving increasingly importance worldwide, especially pollution by gaseous and particulate trace metals (Azad and Kitada 1998; Salam et al. 2003; Begum et al. 2004; and Cachier et al. 2005).

Gaseous pollutants have major negative impacts on health. They also play an important role in environmental changes and changes in atmospheric chemistry. $\mathrm{SO}_{2}$ and $\mathrm{NO}_{2}$ form acids through different chemical reactions in the atmosphere, and these acids are subsequently deposited on land and ocean surfaces as acid rain. It is anticipated that the increasing load of atmospheric sulfur dioxide $\left(\mathrm{SO}_{2}\right)$, nitrogen dioxide $\left(\mathrm{NO}_{2}\right)$, carbon monoxide $(\mathrm{CO})$, and ozone $\left(\mathrm{O}_{3}\right)$ will contribute to global climate change; consequently, it is necessary to quantify the emissions in the very near future.

A great deal of attention has focused on particulate matter (PM) pollution due to their severe health effects, 
especially fine particles. Several epidemiological studies have indicated a strong association between elevated concentrations of inhalable particles $\left(\mathrm{PM}_{10}\right.$ and $\left.\mathrm{PM}_{2.5}\right)$ and increased mortality and morbidity (Perez and Reyes 2002; Lin and Lee 2004; Namdeo and Bell 2005). Particulate matter pollution in the atmosphere primarily consists of micron and sub-micron particles from anthropogenic (motor vehicles, biomass, fossil fuel burning) and natural sources (windblown soils and sea spray) (Cohen 1998). The characterization of fine particles has become an important priority of governments, regulators, and researchers due to their potential impact on health, climate, global warming, and long-range transport (Dockery et al. 1993; IPCC 2001).

Dhaka, Bangladesh, is one of the densely populated megacities in the world, with about 15 million inhabitants within a $300-\mathrm{km}^{2}$ area. Dhaka also suffers from major traffic congestion from both public and private sources. A high concentration of air pollutants, such as black carbon, has already been reported in Dhaka (Salam et al. 2003; Begum et al. 2004). Vehicular emissions, biomass burning for cooking, brick kilns, and construction activities in and around the city are the main contributors to aerosol pollution in Dhaka (Azad and Kitada 1998).

Here, we report the occurrence and characteristics of gaseous $\left(\mathrm{SO}_{2}, \mathrm{NO}_{2}, \mathrm{CO}\right.$ and $\left.\mathrm{O}_{3}\right)$ pollutants, particulate matter [suspended (S)PM, $\mathrm{PM}_{10}$ and $\mathrm{PM}_{2.5}$ ), and heavy metal concentrations [arsenic (As), cadmium (Cd), copper $(\mathrm{Cu})$, iron $(\mathrm{Fe})$, lead $(\mathrm{Pb})$, and inc $(\mathrm{Zn})]$ from January to April, 2006 at five locations in the greater Dhaka area.

\section{Sampling and experimental methods}

\section{Sampling locations in Dhaka, Bangladesh}

Bangladesh is situated in the eastern part of South Asia. It is surrounded by India on the west, the north, and the northeast, Myanmar on the southeast, and the Bay of Bengal on the south (Fig. 1). Dhaka $\left(23^{\prime} 76^{\circ} \mathrm{N}, 90^{\prime} 38^{\circ} \mathrm{E}\right.$, $8 \mathrm{~m}$ a.s.l.) is the capital of Bangladesh. It is also the center of commerce and industries of Bangladesh and is growing rapidly - together with all the problems associated with a megacity. Dhaka is situated in flat land surrounded by rivers (Fig. 1). The five sampling locations were selected to reflect the influences from industrial, commercial, residential, and heavy traffic sources in the highly populated greater Dhaka area: Tower Bhaban (Dhaka University campus), Medinova hospital (Dhanmondi), Noverties Pharmaceuticals (Tejgaon), BCIC Bhaban (Motijheel), and Jahangirnagar University campus (Savar). The Jahangirnagar University (JU) campus site is about $30 \mathrm{~km}$ northwest of Dhaka city center and considered to be an urban background site. The name of the sampling sites and their characteristics are given in Table 1.

\section{Meteorology of Dhaka, Bangladesh}

The climate of Bangladesh is characterized by high temperatures, excessive humidity, and distinctly marked seasonal variations in precipitation. Bangladesh can be divided into four seasons: pre-monsoon (March-May), monsoon (June-September), post-monsoon (OctoberNovember), and winter (December-February). The average meteorological conditions of Dhaka city during the different seasons have been reported by Salam et al. (2003) and Begum et al. (2004). The average winter temperature varies between 9 and $25^{\circ} \mathrm{C}$, and the average summer temperature varies from 24 to $34^{\circ} \mathrm{C}$. The highest relative humidity occurs in July, reaching $99 \%$, and the lowest occur in December, when it is $36 \%$. Moderately higher temperatures are generally observed during the afternoon. Light precipitation occurs during March and April. The average wind velocity during the sampling period at Dhaka was $1.20 \mathrm{~m} \mathrm{~s}^{1}$ (source: Bangladesh Meteorological Department). Backward air trajectories studies (NOAA/ARL 2005) indicated that air masses were transported from north to southeast (January and February) and also south or southwest to north or northwest (March and April).

\section{Particulate matter and trace gas sampling}

Particulate matter and trace gas samplings were performed between January and April 2006 at five locations in Dhaka, Bangladesh (Table 1) using a respirable dust sampler (model $460 \mathrm{NL}$; Enviro-Tech, Rancho Cordova, CA) for $\mathrm{PM}_{10}$, a fine particulate sampler (model APM 550; EnviroTech) for $\mathrm{PM}_{2.5}$, and an organic vapor sampler (model APM 850; Enviro-Tech) for CO measurements with the Indicator Tube method. The PM sampler (model 460 NL; Enviro-Tech) was equipped with impingers to collect the gaseous gases $\left(\mathrm{SO}_{2}, \mathrm{NO}_{2}\right.$, and $\left.\mathrm{O}_{3}\right)$. Ambient air laden with suspended particulates enters the respirable dust sampler through an inlet pipe. As the air enters the cyclone, coarse, non-respirable dust is separated from the air by centrifugal forces acting on the solid particles. These coarse particulates fall through the cyclone and are collected in the sampling bottle fitted at the bottom. The air stream passing through the glass micro-fiber filter (Whatman, Maidstone, UK; size: $20.3 \times 24.4 \mathrm{~cm}$,) paper, which was clamped between the top cover and filter adapter assembly, carries the fine dust forming the respirable fraction $\left(\mathrm{PM}_{10}\right)$. The flow rate of PM collection was determined from the difference of the initial and final flow rate of the instrument gas meter reading. The $\mathrm{PM}_{2.5}$ and $\mathrm{PM}_{10}$ were deposited on 
Fig. 1 a Map of Bangladesh, b Dhaka city map, c map of Dhaka Division showing the location of the sampling sites. Numbers on black solid square refer the sampling sites: 1 BCIC Bhaban, Motijheel, 2 Tower Bhaban, Dhaka University (DU) campus, Ramna, 3 Medinova hospital, Dhanmondi, 4 Noverties Pharmaceutical, Tejgaon, 5 Jahangirnagar University campus

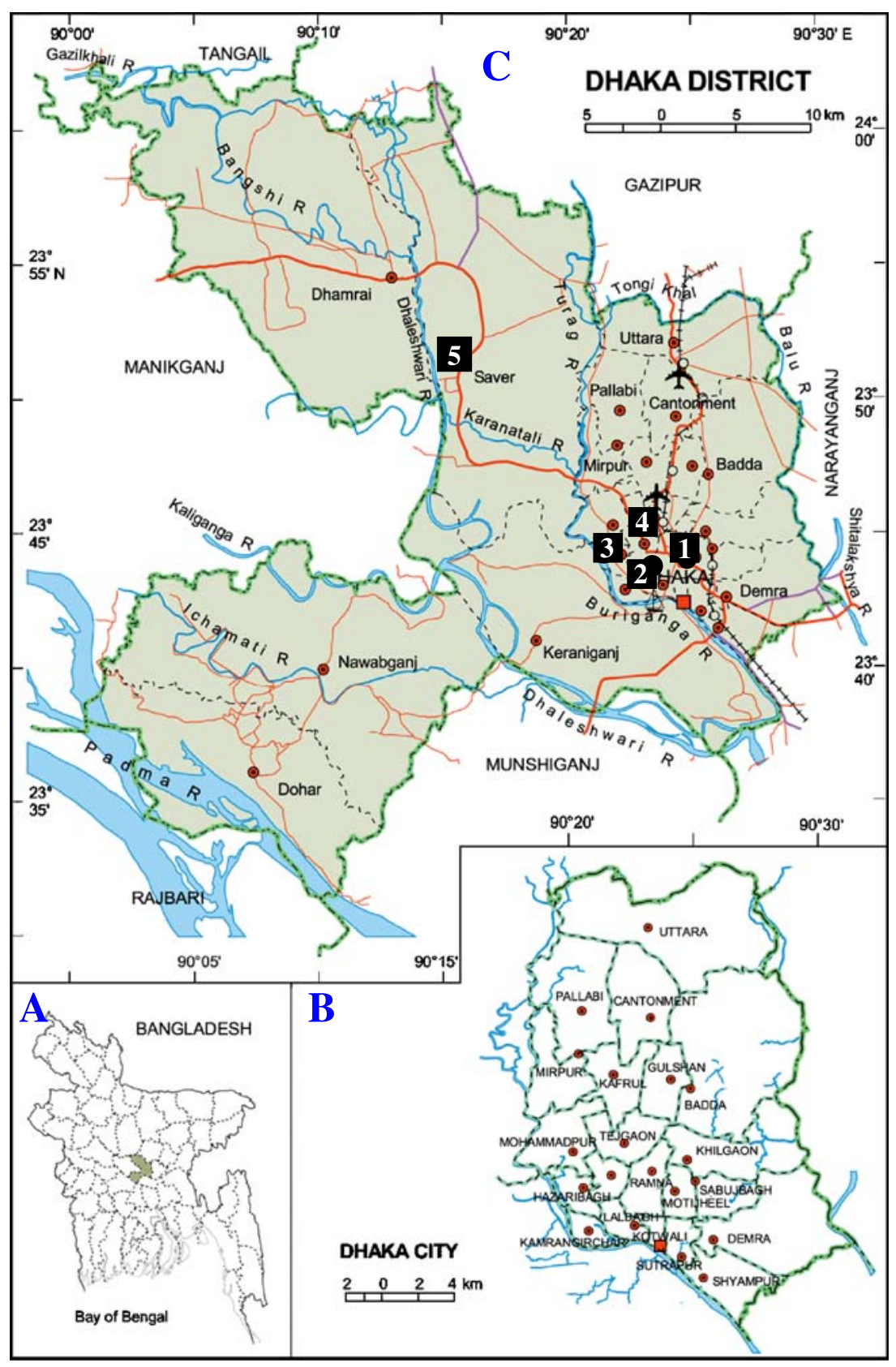

micro-fiber filters (Millipore, Bedford, MA), and those larger than $\mathrm{PM}_{10}$ were collected in the dust Cup Vail. Total SPM was calculated from the sum of the $\mathrm{PM}_{10}$ and PM larger than $\mathrm{PM}_{10}$. A regular calibration is necessary to ensure that the sample collection with both instruments is reliable for $\mathrm{PM}_{10}$ (Enviro-Tech model $460 \mathrm{NL}$ ) and $\mathrm{PM}_{2.5}$ (EnviroTech model APM 550). A factory calibration was carried out before setting up the instruments for the field

Table 1 Description of the sampling locations in the greater Dhaka region, Bangladesh

\begin{tabular}{lll}
\hline Name & Location & Status of the sites \\
\hline Tower Bhaban & Dhaka University (DU) campus & Mainly residential with low traffic \\
BCIC Bhaban & Motijheel, Dhaka & Commercial area with heavy traffic \\
Medinova hospital & Dhanmondi, Dhaka & Residential area with medium traffic \\
Noverties Pharmaceuticals & Tejgaon, Dhaka & Industrial area with heavy traffic \\
Near administrative building & Jahangirnagar University (JU), Savar & Semi urban area with very low traffic
\end{tabular}


measurement. It is absolutely necessary to calibrate the instruments once every 6 months if the instruments are operating 2-3 days per week. The calibrations were done directly by the manufacturer (Envirotech Instruments, New Delhi, India). Sampling instruments were set up on a traffic van (mini truck) for collecting gaseous $\left(\mathrm{SO}_{2}, \mathrm{NO}_{2}\right.$, and $\left.\mathrm{O}_{3}\right)$ and PM from morning to evening (9:00 a.m. to 5:00 p.m. local time), except for $\mathrm{CO}$. The $\mathrm{CO}$ samples were collected for $1 \mathrm{~h}$. The sampling instruments were placed about $3 \mathrm{~m}$ above ground level. The collected samples were brought to the Inorganic and Analytical Research laboratory, Department of Chemistry, Dhaka University. Trace gas $\left(\mathrm{SO}_{2}\right.$, $\mathrm{NO}_{2}, \mathrm{CO}$, and $\mathrm{O}_{3}$ ) samples were analyzed immediately. The PM filters were equilibrated for $48 \mathrm{~h}$ at a controlled temperature $\left(22 \pm 2^{\circ} \mathrm{C}\right)$ and relative humidity $(55 \pm 5 \%)$ prior to weighing and then stored in the refrigerator for further trace metal analysis.

Determination of trace gases

\section{$\mathrm{SO}_{2}$ determination}

The method for measuring $\mathrm{SO}_{2}$ was adapted from West and Gaeke (1956). In this method, air-exposed samples are treated in a solution of potassium tetrachloro-mercurate, and the concentration of $\mathrm{SO}_{2}$ can be measured in the range of $20-1050 \mu \mathrm{g} \mathrm{m}^{-3}$. A dichlorosulphitomercurate complex is formed, which subsequently reacts with pararosaniline and formaldehyde to form the intensely colored pararosaniline methylsulphonic acid (Lyles et al. 1965). We measured the absorbance of the colored solution with an UVspectrophotometer (model AA-680; Shimazdu, Japan) at $560 \mathrm{~nm}$, and the concentration of $\mathrm{SO}_{2}$ was determined based on a calibration curve of five standard solutions ( 0.0 , $4.155,8.29,16.0,24.87$, and $33.16 \mu \mathrm{g} \mathrm{SO}_{2} / 25 \mathrm{ml}$ ). A blank sample was prepared using the same procedure as that for the air-exposed sample for the blank correction.

\section{$\mathrm{NO}_{2}$ determination}

The principle of $\mathrm{NO}_{2}$ measurement in atmospheric samples was described by Jacob and Hochheiser (1958); the normal range of this method is $9-750 \mu \mathrm{g} \mathrm{m}^{-3}$. In this method, airexposed samples were treated with sodium hydrogen and sodium arsenite. The sample solution was again treated with phosphoric acids, sulfanilamide, and a N-(1-naphthyl)ethylenediamine di-hydrochloride (NEDA) solution. A colored solution was produced, and the absorbance of the colored solution was measured with a UV-spectrophotometer (model AA-6801 Shimazdu) at $540 \mathrm{~nm}$. The concentrations of $\mathrm{NO}_{2}$ were determined from the calibration curve of five standard solutions $(0.0,1.0,2.0,3.0,5.0,7.0$, and $9.0 \mu \mathrm{g}$ $\mathrm{NO}_{2} / 50 \mathrm{ml}$ ). A blank sample was also prepared using the same procedure as that for the air-exposed sample for the blank correction.

\section{CO determination}

The concentration of $\mathrm{CO}$ was determined by Indicator Tube Method. The air was passed through the tube by an aspirator. After $1 \mathrm{~h}$ of sampling, the color of the fixed portion of the tube was matched with given chart value (APM 850 model; Enviro-Tech, India). The concentration was calculated using the equations: $\mathrm{CO}$ concentration $\left(\mu \mathrm{gm}^{-3}\right)=\left[\left(\right.\right.$ Chart value of 1 Squeeze $\left.\left.\times 0.75 \times 10^{6}\right) / \mathrm{F}\right]$, where 0.75 is the factor for the density of $\mathrm{CO}, 10^{6}$ is the conversation factor for both air volume (from liter to cubic meter) and milligram to microgram, and $\mathrm{F}$ is the total volume for air passed (1) through the indicator tube. The total volume of air passed through the $\mathrm{CO}$ indicator tube $=$ average flow rate $(\mathrm{lpm}) \mathrm{x}$ time $(\mathrm{min})$.

\section{$\mathrm{O}_{3}$ determination}

An absorbing reagent was prepared with $\mathrm{KH}_{2} \mathrm{PO}_{4}$, $\mathrm{Na}_{2} \mathrm{HPO}_{4}$, and $\mathrm{KI}$ for $\mathrm{O}_{3}$ concentration determination. The air-exposed samples were treated with the absorbing reagents, which produced a colored solution. The absorbance of the colored solutions was measured at $352 \mathrm{~nm}$ against a blank using a UV-spectrophotometer (model AA680; Shimazdu). The concentration of $\mathrm{O}_{3}$ was measured from a calibration curve of five standard solutions $(0.0,1.0$, 3.0, 5.0, 7.0, and $9.0 \mu \mathrm{g} / 25 \mathrm{ml})$. Blank correction was performed by preparing a blank sample using the same procedure as that used for the air-exposed samples.

\section{Determination of PM}

The aerosol masses for $\mathrm{PM}_{2.5}$ and $\mathrm{PM}_{10}$ were determined by weighing the filters before and after exposure at ambient temperature and atmospheric pressure with an OHAUS analytical balance (model no. AR1140; OHAUS, Pine Brook, NJ). Total suspended particulate (TSP) matter was determined from the sum of $\mathrm{PM}_{10}$ and particles larger than $\mathrm{PM}_{10}$. The mass of PM larger than $\mathrm{PM}_{10}$ was determined from the initial and final weight of the dust Cup Vail. Samples were transported from the sampling site to the laboratory and kept them in a refrigerator until analysis to minimize volatilization. Blank correction was performed by preparing field blanks using the same procedure as that for the PM samples.

Determination of heavy metals

An atomic absorption spectrophotometer (AAS; model AA680; Shimadzu) was used to determine the concentrations 
of heavy metals ( $\mathrm{As}, \mathrm{Cd}, \mathrm{Cu}, \mathrm{Fe}, \mathrm{Pb}, \mathrm{Zn}$ ) in the $\mathrm{PM}_{2.5}$ size fraction during the period January-April 2006. The $\mathrm{PM}_{2.5^{-}}$ loaded filters were extracted in an acid mixture to remove heavy metals. Each filter (diameter $4.7 \mathrm{~cm}$ ) was placed in $30 \mathrm{ml}$ concentrated nitric acid (70\%) and $10 \mathrm{ml}$ hydrogen peroxide $(30 \%)$ solution in a digestion vessel. The digestion vessels were placed on a sand bath and heated to $180^{\circ} \mathrm{C}$ for about $1 \mathrm{~h}$ until the acid solution had evaporated. The procedure was repeated twice and was continued until the residue was almost dry. Upon cooling, $60 \mathrm{ml}$ water was added and agitated carefully. The solution was filtered into a 100 -ml volumetric flask, diluted to the mark with de-ionized water, and used for the trace metal analysis with AAS. One unexposed filter was prepared as a blank using the same procedure as that followed for the air-exposed filter.

For the determination of the heavy metal concentrations, calibration curves for each metal were prepared with five standard solutions at different concentrations. Metal solutions were aspirated into the flame of the AAS, where ions are reduced to the atomic state, and absorbed light can be measured quantitatively at a particular wavelength. However, the concentrations of each metal were determined from the standard calibration curve of the individual metal.

\section{Results and discussion}

Overview of the experimental results

Assessment of the concentrations of ambient air $\mathrm{PM}_{10}$ and $\mathrm{PM}_{2.5}$, trace gases $\left(\mathrm{SO}_{2}, \mathrm{NO}_{2}, \mathrm{CO}\right.$ and $\left.\mathrm{O}_{3}\right)$, and heavy metals ( $\mathrm{As}, \mathrm{Cd}, \mathrm{Cu}, \mathrm{Fe}, \mathrm{Pb}, \mathrm{Zn}$ ) were determined on $\mathrm{PM}_{2.5}$ size fractions at five locations in Dhaka, Bangladesh from January to April 2006. The sampling sites were located at Tower Bhaban (Dhaka University campus), Medinova hospital (Dhanmondi), Noverties Pharmaceuticals (Tejgaon), BCIC Bhaban (Motijheel), and Jahangirnagar University campus (Savar). The description of the sampling sites are given in Table 1 and also shown in Fig. 1. The concentrations of measured components varied between residential, industrial, and semi-urban sites in the greater Dhaka area and also varied slightly temporally between January and April 2006. The concentrations of trace gases remained almost constant over the entire sampling period, whereas those of the PM varied from 1 month to the other, with higher concentrations of both $\mathrm{PM}_{10}$ and $\mathrm{PM}_{2.5}$ observed in January and lower concentrations in April. Details of the experimental results were given in Tables 2, 3, 4 .

\section{Trace gases}

The atmospheric trace gases $\left(\mathrm{SO}_{2}, \mathrm{NO}_{2}, \mathrm{CO}\right.$ and $\left.\mathrm{O}_{3}\right)$ were measured at five locations in Dhaka during the period of
January to April, 2006. Samples were collected once in a week at each location. The sampling time was $8 \mathrm{~h}$ for $\mathrm{SO}_{2}$, $\mathrm{NO}_{2}$, and $\mathrm{O}_{3}$ and $1 \mathrm{~h}$ for $\mathrm{CO}$. The samples were collected in an impinger attached to the $\mathrm{PM}$ samplers for $\mathrm{SO}_{2}, \mathrm{NO}_{2}$, and $\mathrm{O}_{3}$, and an organic vapor sampler was used for $\mathrm{CO}$ measurements with the Indicator Tube method. The overall average value of $\mathrm{SO}_{2}$ at five sampling locations in Dhaka was $48 \mu \mathrm{g} \mathrm{m}^{-3}$, which is very close to the annual average of the World Health Organization's (WHO) guideline values for the European Union (WHO 2000: $50 \mu \mathrm{g} \mathrm{m}^{-3}$ ). Because the total sampling period in our study was about 4 months [ $8 \mathrm{~h}$ daily for all gases except $\mathrm{CO}(1 \mathrm{~h})]$ and extended from the winter through the beginning of the monsoon season, it can be considered to be an average for the whole year. The highest concentration $\left(76.8 \mu \mathrm{g} \mathrm{m}^{-3}\right)$ of $\mathrm{SO}_{2}$ was found in the commercial and heavy traffic areas (BCIC Bhaban, Motijheel), and the lowest concentration $\left(20.7 \mu \mathrm{g} \mathrm{m}^{-3}\right)$ was found in the semi-urban area (Jahangirnagar University campus, Savar). The elevated concentration of $\mathrm{SO}_{2}$ in the city center is probably due to the high content of sulfur in fossil fuel. Azad and Kitada (1998) reported that the primary source of $\mathrm{SO}_{2}$ in Dhaka is traffic fuels $(55.8 \%)$ followed by brick fields $(28.8 \%)$, industry $(10.5 \%)$, and others (about 5\%); they also reported high $\mathrm{SO}_{2}$ concentrations in the southern industrial area, where the highest value was about $286 \mu \mathrm{g} \mathrm{m}^{-3}$.

The total average concentration of $\mathrm{NO}_{2}$ at five locations in Dhaka was $21.0 \mu \mathrm{g} \mathrm{m}^{-3}$, which is about half of the annual WHO guideline value $2005\left(40 \mu \mathrm{g} \mathrm{m}^{-3}\right)$. The $\mathrm{NO}_{2}$ enters the atmosphere from various natural and anthropogenic sources, including lighting, action of microorganisms on nitrogen-based fertilizer, but the most important and major anthropogenic source is the combustion of fossil fuel in traffic. The highest concentration of $\mathrm{NO}_{2}\left(40 \mu \mathrm{g} \mathrm{m}^{-3}\right)$ was found at Medinava hospital, Dhanmondi site, with medium traffic, whereas the lowest concentration $(5.0 \mu \mathrm{g}$ $\mathrm{m}^{-3}$ ) was found at Jahangirnagar University, Savar, a semiurban location. Azad and Kitada 1998 measured $\mathrm{NO}_{2}$ concentrations with molecular diffusion tubes in Dhaka, Bangladesh. They reported that the highest 10-day average was about $65.8 \mu \mathrm{g} \mathrm{m}^{-3}$, with higher concentrations appearing in the city center along the main roads of Dhaka. Motor vehicles and brick fields were speculated to be the two major emission sources in Dhaka.

The measured $\mathrm{CO}$ values varied between industrial, urban, and semi-urban sites. The highest concentration (334 $\mu \mathrm{g} \mathrm{m}^{-3}$ ) of $\mathrm{CO}$ was observed at the industrial site (Novarties, Tejgaon), whereas the lowest value $\left(42 \mu \mathrm{g} \mathrm{m}^{-3}\right)$ was found in the semi-urban area (Jahangirnagar University, Savar). The highest concentration of $\mathrm{CO}$ at the industrial sites is presumably due to the incomplete conversion of fossil fuel during different mechanical and industrial processes. However, the overall (4 months at five sampling 
Table 2 Concentrations of atmospheric trace gases at five different locations in greater Dhaka, Bangladesh

\begin{tabular}{|c|c|c|c|c|}
\hline Sampling Location & $\mathrm{SO}_{2}$ & $\mathrm{NO}_{2}$ & $\mathrm{CO}$ & $\mathrm{O}_{3}$ \\
\hline Tower Bhaban, Dhaka university & $30.5( \pm 7)$ & $25.0( \pm 5)$ & $90.8( \pm 9)$ & $9.81( \pm 3)$ \\
\hline BCIC Bhaban, Motijheel & $76.8( \pm 11)$ & $10.3( \pm 3)$ & $238.2( \pm 14)$ & $19.6( \pm 7)$ \\
\hline Medinova hospital, Dhanmondi R/A & $49.1( \pm 5)$ & $40.5( \pm 8)$ & $125( \pm 12)$ & $29.4( \pm 13)$ \\
\hline Novarties Pharmaceuticals, Tejgaon & $64.3( \pm 15)$ & $23.6( \pm 5)$ & $334.2( \pm 22)$ & $3.92( \pm 2)$ \\
\hline Jahangirnagar University, Savar & $20.7( \pm 6)$ & $5.53( \pm 2)$ & $41.7( \pm 5)$ & $76.5( \pm 18)$ \\
\hline Average $(n=75)$ & 48.3 & 21.0 & 166.0 & 27.9 \\
\hline
\end{tabular}

Units are in $\mu \mathrm{g} \mathrm{m}^{-3}$

Samples were collected once a week at each location (each location has a total of 15 samples). Sampling time was $8 \mathrm{~h}$ for $\mathrm{SO}_{2}, \mathrm{NO}_{2}$, and $\mathrm{O}_{3}$, and $1 \mathrm{~h}$ for $\mathrm{CO}$

locations) average value of CO in Dhaka was $166 \mu \mathrm{g} \mathrm{m} \mathrm{m}^{-3}$ (1-h sampling time daily).

The total average concentration of $\mathrm{O}_{3}$ at five sampling sites in Dhaka was $28 \mu \mathrm{g} \mathrm{m}^{-3}$, which is much lower than the daily maximum value $\left(100 \mu \mathrm{g} \mathrm{m}^{-3}\right.$; WHO 2005). However, $\mathrm{O}_{3}$ is one of the most ubiquitous and toxic pollutants found in ambient air. A higher concentration $\left(76.5 \mu \mathrm{g} \mathrm{m}^{-3}\right)$ of $\mathrm{O}_{3}$ was found in the semi-urban area (Jahangirnagar University campus, Savar), and the lowest concentration $\left(3.92 \mu \mathrm{g} \mathrm{m}^{-3}\right)$ was found in the industrial area (Noverties, Tejgaon).

\section{Particulate matter}

Atmospheric particulate matter $\left(\mathrm{PM}_{10}, \mathrm{PM}_{2.5}\right)$ was collected on micro-fiber filters with low-volume samplers from 9:00 A.M. to 5:00 P.M. ( $8 \mathrm{~h}$ on average) between January and April 2006 at five locations in Dhaka, Bangladesh. Total suspended particulate matter was calculated from the sum of the $\mathrm{PM}_{10}$ and particles larger than $\mathrm{PM}_{10}$ (collected in the dust Cup Vail). The total average concentration of SPM in the ambient air of Dhaka was $262.6 \mu \mathrm{g} \mathrm{m}^{-3}$. The World Bank and Department of the Environment of Bangladesh found SMP concentrations of $665-2456 \mu \mathrm{g} \mathrm{m}^{-3}$ at Farmgate, Dhaka (Core 1998) based on 8-h measurements at several locations along busy roads in Dhaka city. The difference between these 1998 results and those of our study indicates that the ambient concentrations of SPM in Dhaka are decreasing remarkably. However, our measurements showed that the maximum daily average (exposure time: $8 \mathrm{~h}$ daily) concentration of SPM was $570 \mu \mathrm{g} \mathrm{m}^{-3}$ at Motijheel in January, 2006. The SPM concentrations among the five sampling sites varied from $126.2 \mathrm{\mu g} \mathrm{m}^{-3}$ at Jahangirnagar University (JU) campus, Savar to $523.0 \mathrm{\mu g} \mathrm{m}^{-3}$ at BCIC Bhaban, Motijheel (Table 3). The causes of the higher SPM values in Dhaka may be road dusts, construction activities, incomplete combustion of fossil fuel from traffic vehicles and brick kilns, and long-range transport (Begum et al. 2004).

The total average concentrations of $\mathrm{PM}_{10}$ and $\mathrm{PM}_{2.5}$ were 75.5 and $66.2 \mu \mathrm{g} \mathrm{m}^{-3}$, respectively, at five locations in the greater Dhaka area. At the five sampling locations in Dhaka, the average mass concentrations varied from 62.0 to $91.2 \mu \mathrm{g} \mathrm{m}^{-3}$ for $\mathrm{PM}_{10}$, whereas these ranged between 54.2 and $80.5 \mu \mathrm{g} \mathrm{m}^{-3}$ for $\mathrm{PM}_{2.5}$ (Table 3). Chuersuwan et al. (2008) reported mass concentrations of $57.6-108.1 \mu \mathrm{g} \mathrm{m}^{-3}$ for $\mathrm{PM}_{10}$ and between 69.0 and $37.9 \mu \mathrm{g} \mathrm{m}^{-3}$ for $\mathrm{PM}_{2.5}$ at four sampling sites in Bangkok, Thailand. The $\mathrm{PM}_{10}$ mass concentrations in Kanpur, India were much higher than those we found for Dhaka. At three sampling locations in Kanpur, the average $\mathrm{PM}_{10}$ mass concentration was $211 \mu \mathrm{g} \mathrm{m} \mathrm{m}^{-3}$ and

Table 3 Concentrations of particulate matter of different size fractions $(\mu \mathrm{m})$ at five different locations in greater Dhaka between January and April 2006

\begin{tabular}{|c|c|c|c|c|c|}
\hline Sampling Sites & SPM & $\mathrm{PM}_{10}$ & $\mathrm{PM}_{2.5}$ & $\mathrm{PM}_{2.5-10}$ & $\mathrm{PM}_{2.5} / \mathrm{PM}_{10}$ \\
\hline Tower Bhaban, DU campus & $130.8( \pm 11)$ & $66.2( \pm 9)$ & $54.2( \pm 7)$ & 12.0 & 0.82 \\
\hline Medinova Hospital, Dhanmondi & $386.2( \pm 20)$ & $73.7( \pm 16)$ & $63.6( \pm 8)$ & 10.1 & 0.86 \\
\hline Novarties Pharmaceuticals, Tejgaon & $147( \pm 10)$ & $91.2( \pm 5)$ & $80.5( \pm 9)$ & 10.7 & 0.88 \\
\hline Jahangirnagar University, Savar & $126.2( \pm 14)$ & $62( \pm 10)$ & $57.1( \pm 6)$ & 4.90 & 0.92 \\
\hline BCIC Bhaban, Motijheel & $523( \pm 29)$ & $84.5( \pm 7)$ & $75.6( \pm 13)$ & 8.90 & 0.89 \\
\hline Average $(n=75)$ & 263 & 75.5 & 66.2 & 9.3 & 0.88 \\
\hline
\end{tabular}

SPM Suspended Particulate Matter, PM Particulate Matter

Units are in $\mu \mathrm{g} \mathrm{m} \mathrm{m}^{-3}$

The sampling time was $8 \mathrm{~h}$. Samples were collected once a week for each sampling location (each location has a total of 15 samples) 
Table 4 Concentrations of trace metals at five different sampling sites in greater Dhaka for the size fraction $\mathrm{PM}_{2.5}$ between January and April 2006

\begin{tabular}{|c|c|c|c|c|c|c|}
\hline Sampling Location & As & $\mathrm{Cd}$ & $\mathrm{Cu}$ & $\mathrm{Fe}$ & $\mathrm{Pb}$ & $\mathrm{Zn}$ \\
\hline Tower Bhaban, DU campus & $6.2( \pm 3)$ & $0.19( \pm 0.1)$ & $30.9( \pm 12)$ & $244( \pm 34)$ & $103( \pm 44)$ & $426( \pm 45)$ \\
\hline BCIC Bhaban, Motijheel & $6.6( \pm 2)$ & $5.04( \pm 2)$ & $90.7( \pm 28)$ & $557( \pm 43)$ & $335( \pm 26)$ & $428( \pm 59)$ \\
\hline Medinova hospital, Dhanmondi & $4.3( \pm 2)$ & $11.5( \pm 3)$ & $132.4( \pm 45)$ & $469( \pm 53)$ & $227( \pm 33)$ & $428( \pm 58)$ \\
\hline Novarties Pharmaceuticals, Tejgaon & $7.9( \pm 3)$ & $34.9( \pm 9)$ & $92.6( \pm 60)$ & $669( \pm 92)$ & $305( \pm 27)$ & $516( \pm 35)$ \\
\hline Jahangirnagar University, Savar & $6.4( \pm 4)$ & $14.3( \pm 6)$ & $127.1( \pm 35)$ & $224( \pm 50)$ & $51( \pm 12)$ & $108( \pm 22)$ \\
\hline Total Average $(n=75)$ & 6.28 & 13.2 & 95 & 433 & 204 & 381 \\
\hline
\end{tabular}

All units are in $\mathrm{ng} \mathrm{m}^{-3}$.

The sampling time was $8 \mathrm{~h}$ daily. Samples were collected once a week at each sampling location (each location has a total 15 samples)

ranged from 80 to $281 \mu \mathrm{g} \mathrm{m}^{-3}$ (Sharma and Maloo 2005). The average $\mathrm{PM}_{2.5}$ mass concentration at the same locations, $101 \mathrm{\mu g} \mathrm{m}^{-3}$, was also much higher than that at Dhaka, ranging from 65 to $146 \mu \mathrm{g} \mathrm{m}^{-3}$ (Sharma and Maloo 2005). The ratio between $\mathrm{PM}_{2.5}$ and $\mathrm{PM}_{10}$ in Dhaka shows that particulate mass mostly derived from fine fraction, which is very harmful for human health. $\mathrm{PM}_{2.5}$ mass is about $88 \%$ of that of $\mathrm{PM}_{10}$, which indicates that the source of $\mathrm{PM}$ is mostly from fossil fuel. Begum et al. 2004 also reported that vehicles normally produce more fine particles $\left(\mathrm{PM}_{2.5}\right)$ than coarse ones $\left(\mathrm{PM}_{2.5-10}\right)$, with the latter mostly originating from mechanical processes. The concentrations of the coarse particles $\left(\mathrm{PM}_{2.5-10}\right)$ varied from 12.0 to $9.31 \mathrm{~g} \mathrm{~m} \mathrm{~m}^{-3}$, and the average concentration for the coarse fraction was $9.31 \mathrm{\mu g} \mathrm{m}^{-3}$ (Table 3). However, the elevated concentrations of PM observed in Dhaka, Bangladesh are still lower than those reported for Southeast Asian sites (Smith et al. 1996; Sharma and Maloo 2005).

\section{Heavy metals}

The concentrations of selected trace metals were determined at five locations in the greater Dhaka region for $\mathrm{PM}_{2.5}$ in the period from January to April 2006. $\mathrm{PM}_{2.5}$ samples were collected on fiber filters (diameter $4.7 \mathrm{~cm}$ ) with a low-volume sampler. An AAS was used to determine the concentrations of heavy metals ( $\mathrm{As}, \mathrm{Cd}, \mathrm{Cu}, \mathrm{Fe}, \mathrm{Pb}$, $\mathrm{Zn})$. The measured concentrations of the heavy metals are given in Table 4.

\section{Arsenic}

Arsenic is a major ground water pollutant in many parts of Bangladesh. Millions of people are affected by As-related diseases in Bangladesh due to contaminated drinking water. It is therefore very important to check the As concentrations in the air of Bangladesh. The total average As concentration at the five locations in Dhaka was $6.3 \mathrm{ng} \mathrm{m}^{-3}$. However, the concentration of As varied from $4.3 \mathrm{ng} \mathrm{m}^{-3}$ (Medinova hospital, Dhanmondi) to $7.9 \mathrm{ng} \mathrm{m}^{-3}$ (Noverties Pharmaceutical, Tejgaon) (Table 4). Unexpectedly high As concentrations $\left(325 \mathrm{ng} \mathrm{m}^{-3}\right)$ were observed at all four sites in Bangkok, Thailand (Chuersuwan et al. 2008).

\section{Cadmium}

Average Cd concentrations ranged from 0.2 to $34.9 \mathrm{ng} \mathrm{m}^{-3}$. The lowest value among these five sites was found at Tower Bhaban, Dhaka University campus (residential area), whereas the highest value was observed at Noverties Pharmaceutical, Tejgaon Industrial area. The higher $\mathrm{Cd}$ concentration at the industrial site may be due to the release of $\mathrm{Cd}$ from different industrial mechanical processes. The total average of $\mathrm{Cd}$ in Dhaka $\left(13 \mathrm{ng} \mathrm{m}^{-3}\right)$ is slightly higher than that previously reported by Salam et al. 2003, is comparable with those found in Spain (Querol et al. 2002), but if three- to fourfold lower than the values reported for other Southeast Asian sites (Sharma and Patil 1992; Smith et al. 1996).

\section{Copper}

The average $\mathrm{Cu}$ concentrations varied from $31 \mathrm{ng} \mathrm{m}^{-3}$ (Tower Bhaban, Dhaka University campus) to $132 \mathrm{ng} \mathrm{m}^{-3}$ (Medinova hospital, Dhanmondi) (Table 4). The average value of $\mathrm{Cu}$ was $95 \mathrm{ng} \mathrm{m}^{-3}$ for $\mathrm{PM}_{2.5}$, which is about twofold higher than the value ( $54 \mathrm{ng} \mathrm{m}^{-3}$ for TSP) obtained by Salam et al. 2003. The average $\mathrm{Cu}$ concentration of five locations in Dhaka, Bangladesh for $\mathrm{PM}_{2.5}$ was slightly higher than that $\left(65 \mathrm{ng} \mathrm{m}^{-3}\right)$ found at four sites in Bangkok, Thailand (Chuersuwan et al. 2008).

\section{Iron}

The average $\mathrm{Fe}$ concentration varied from $225 \mathrm{ng} \mathrm{gm}^{-3}$ (Jahangirnagar University, Savar) to $669 \mathrm{ng} \mathrm{m}^{-3}$ (Noverties Pharmaceutical, Tejgaon). The highest value of Fe (669 ng $\mathrm{m}^{-3}$ ) was observed at the Tejgaon industrial area, probably 
due to the industrial activities there. The lower value of $\mathrm{Fe}$ (225 $\mathrm{ng} \mathrm{m}^{-3}$ ) at Jahangirnagar University Campus may be due to the lack of industrial activity at this site and also because there is less traffic than at the Noverties Pharmaceutical, Tejgaon site. Iron exhibited relatively higher values at all five sites. The average estimated value of $\mathrm{Fe}$ was $433 \mathrm{ng} \mathrm{m}^{-3}$. While $\mathrm{Fe}$ may originate from soil dusts, poorly managed transport, and building construction, among others, the major sources of $\mathrm{Fe}$ are both anthropogenic and crustal in origin, including iron and steel manufacturing units and the weathering of exposed $\mathrm{Fe}$ in urban areas. However, the overwhelming source of $\mathrm{Fe}$ particles in the atmosphere is from crustal weathering. The average value of $\mathrm{Fe}$ was $433 \mathrm{ng} \mathrm{m}^{-3}$, which is higher than the concentration found in Los Angeles, USA and Spain (Querol et al. 2002) and also lower than that reported for Asian sites (Fung and Wong 1995; Balachandran et al. 2000).

\section{Lead}

The average $\mathrm{Pb}$ concentration varied from $51 \mathrm{ng} \mathrm{m}^{-3}$ (Jahangirnagar University, Savar) to $335 \mathrm{ng} \mathrm{m}^{-3}$ (BCIC Bhaban, Motijheel) (Table 4). The higher value of $\mathrm{Pb}$ may be due to the presence of heavy traffic at the Motijheel area, while the lower value may be due to relatively lower level of traffic. Lead compounds accumulate with PM in the atmosphere and gradually settle on the Earth's surface. The level of $\mathrm{Pb}$ in rural areas in Bangladesh was found to be below the detection limit (Salam et al. 2003). We found the total average concentration of $\mathrm{Pb}$ at the five sites in Dhaka to be $204 \mathrm{ng} \mathrm{m}^{-3}$ of $\mathrm{PM}_{2.5}$ (Table 4), which is about half the WHO 1999 guideline value of $500 \mathrm{ng} \mathrm{m}^{-3}$ for urban areas. Scientists at the Bangladesh Atomic Energy Commission (BAEC) observed that Dhaka was the most Pb-polluted city in the world for a part of 1996. A 17-month survey conducted by the scientists of BAEC detected $463 \mathrm{ng} \mathrm{m}^{-3}$ $\mathrm{Pb}$ for $\mathrm{PM}_{2.5}$ in Dhaka air during the dry months (between November 1994 and January 1996) (Khaliquzzaman et al. 1997). However, the atmospheric $\mathrm{Pb}$ concentration in Dhaka is decreasing gradually, presumably due to the ban on leaded gasoline in Bangladesh, although it is still higher than that found in European cities (NILU 2002; Manalis et al. 2005) and Far East Asian sites Taiwan (133 $\mathrm{ng} \mathrm{m}^{-3}$ by Fung and Wong 1995). However, it is lower than that reported for Southeast Asian Sites such as Karachi, Pakistan, and Delhi, Mumbai, and Kanpur, India (Smith et al. 1996; Balachandran et al. 2000; Kumar et al. 2001; Sharma and Maloo 2005).

\section{Zinc}

The average $\mathrm{Zn}$ concentrations varied from $103 \mathrm{ng} \mathrm{m}^{-3}$ (Jahangirnagar University, Savar) to $516 \mathrm{ng} \mathrm{m}^{-3}$ (Noverties
Pharmaceuticals, Tejgaon) (Table 4). The highest value of $\mathrm{Zn}$ at Noverties Pharmaceuticals was probably due to the industrial release of $\mathrm{Zn}$ at this location, while the lowest value at Jahangirnagar University campus may be the result of relatively less traffic. The average value of $\mathrm{Zn}$ for $\mathrm{PM}_{2.5}$ was $381 \mathrm{ng} \mathrm{m}^{-3}$, which is much lower than the value (801 $\mathrm{ng} \mathrm{m}^{-3}$ ) obtained at a previous measurement by Salam et al. 2003 for TSP. Elevated concentrations of $\mathrm{Zn}$ have also been observed for other Southeast Asian sites (e.g., Lahore, Pakistan; Smith et al. 1996). The Zn concentration at Dhaka was much lower than that at Delhi (Balachadran et al. 2000) and Kanpur (Sharma and Maloo 2005), India, but much higher than that found in Norway (NILU 2002).

\section{Conclusions}

Atmospheric pollution at five locations in greater Dhaka, Bangladesh, was characterized in terms of trace gases, $\mathrm{PM}$, and heavy metals. The average concentration of $\mathrm{O}_{3}$ in the greater Dhaka area was lower than the WHO guidelines value (WHO 2005). Elevated concentrations of PM were observed in Dhaka, but these were still lower than those reported for Southeast Asian sites. Particulate mass originates mostly from fine particles (about $88 \%$ of $\mathrm{PM}_{10}$ mass was from $\mathrm{PM}_{2.5}$ ). The concentrations of $\mathrm{Pb}, \mathrm{Zn}, \mathrm{Cu}$, $\mathrm{Fe}$, As, and $\mathrm{Cd}$ were much lower than the previous measurements in Dhaka city. In particular, the $\mathrm{Pb}$ concentration is decreasing due to ban of leaded fuel in Bangladesh.

Acknowledgments The authors thank to the Ministry of Science Information and Communication Technology for granting a special allocation to carry out the current research work. We gratefully acknowledge two reviewers for their helpful suggestions.

Open Access This article is distributed under the terms of the Creative Commons Attribution Noncommercial License which permits any noncommercial use, distribution, and reproduction in any medium, provided the original author(s) and source are credited.

\section{References}

Azad AK, Kitada T (1998) Characteristics of the air pollution in the city of Dhaka, Bangladesh in winter. Atmos Environ 32:19912005. doi:10.1016/S1352-2310(97)00508-6

Balachandran S, Meena BR, Khillare PS (2000) Particle size distribution and its elemental composition in the ambient air of Delhi. Environ Int 26:49-54. doi:10.1016/S0160-4120(00) 00077-5

Begum BA, Kim E, Biswas SK, Hopke PK (2004) Investigation of sources of atmospheric aerosol at urban and semi-urban areas in Bangladesh. Atmos Environ 38:3025-3038. doi:10.1016/j. atmosenv.2004.02.042

Cachier H, Aulagnier F, Sarda R, Gautier F, Masclet P, Besombes JL et al (2005) Aerosol studies during the ESCOMPTE experiment: 
an overview. Atmos Res 74:547. doi:10.1016/j.atmosres. 2004.06.013

Chuersuwan N, Nimrat S, Lekphet S, Kerdkumrai T (2008) Levels and major sources of $\mathrm{PM}_{2.5}$ and $\mathrm{PM}_{10}$ in Bangkok Metropolitan Region. Environ Int 34:671-677. doi:10.1016/j.envint.2007. 12.018

Cohen DD (1998) Characterization of atmospheric fine particle using IBA techniques. Nucl Instrum Methods 136:14-22. doi:10.1016/ S0168-583X(97)00658-7

Core J (1998) Sources of air pollution and control options. Paper presented in the Consultative Meeting of World Bank and DoE. Government of Bangladesh, Dhaka

Decker EH, Elliot S, Smith FA, Blake DR, Rowland FS (2000) Energy and material flow through the urban environment. Annu Rev Energy Environ 25:685-740. doi:10.1146/annurev.energy. 25.1.685

Dockery DW, Pope CA, Xu X, Spengler JD, Ware JH, Fay ME et al (1993) An association between air pollution and mortality in six US citites. N Engl J Med 329:1753-1759. doi:10.1056/ NEJM199312093292401

Fung YS, Wong LWY (1995) Apportionment of air pollution sources by receptor models in Hong Kong. Atmos Environ 29:20412048. doi:10.1016/1352-2310(94)00239-H

IPCC (International Panel on Climate Change) (2001) The third assessment report of Working Group I of the Intergovernmental Panel on Climate Change. Technical summary. IPCC, Shanghai

Jacob MB, Hochheiser S (1958) Continuous sampling and ultra-micro determination of nitrogen dioxide in air. Anal Chem 30:426-431. doi:10.1021/ac60135a032

Khaliquzzaman M, Biswas SK, Tarafdar SA, Islam A, Khan AH (1997) Trace element composition of size fractionated airborne particulate matter in urban and rural areas in Bangladesh. Report AECD/AFD-CH/6-4

Kumar AV, Patil RS, Nambi KSV (2001) Source apportionment of suspended particulate matter at two traffic junctions in Mumbai, India. Atmos Environ 35:4245-4251. doi:10.1016/S1352-2310 (01)00258-8

Lin J, Lee LC (2004) Characterization of the concentration and distribution of urban submicron $\left(\mathrm{PM}_{1}\right)$ aerosol particles. Atmos Environ 38:469-475. doi:10.1016/j.atmosenv.2003.09.056

Lyles GR, Dowling FB, Blanchard VJ (1965) Quantitative determination of formaldehyde in parts per hundred million concentration level. J Air Pollut Control Assoc 15:106-114

Manalis N, Grivas G, Protonotarios V, Moutsatsou A, Samara C, Chaloulakou A (2005) Toxic metal content of particulate matter $\left(\mathrm{PM}_{10}\right)$, within the Greater Area of Athens. Chemosphere 60:557-566. doi:10.1016/j.chemosphere.2005.01.003

Mayer M, Wang C, Webster M, Prinn RG (2000) Linking local air pollution to global chemistry and climate. J Geophys Res 105:22 869-22 896

Molina MJ, Molina LT (2004) Megacities and atmospheric pollution. J Air Waste Manage Assoc 54:644-680
Molina LT, Molina MJ, Slott R, Kolb CE, Gbor PK, Meng F et al (2004) Air quality in selected megacities. Crit Rev 10[Suppl]. Available at: http://www.awma.org

Namdeo A, Bell MC (2005) Characteristics and health implications of fine and coarse particulates at roadside, urban background and rural sites in UK. Environ Int 31:565-573. doi:10.1016/j. envint.2004.09.026

NILU (Norwegian Institute of Air Research) (2002) Heavy metals and POPS within the EMEP region 2000. Report -EMEP/CCC-9/ 2002, Norwegian Institute of Air Research, Kjeller

NOAA/ARL (National Oceanic and Atmospheric Administration/Air Resources Laboratory) (2005) HYSPLIT4 model. Available at: http://www.arl.noaa.gov/ready/hysplit4.html). NOAA Air Resources Laboratory, Silver Spring

Perez P, Reyes J (2002) Prediction of maximum of 24-h average of $\mathrm{PM}_{10}$ concentrations $30 \mathrm{~h}$ in advance in Santiago, Chile. Atmos Environ 36:4555-4561. doi:10.1016/S1352-2310(02) 00419-3

Querol X, Lastuey A, De La Rosa J, Sanchez A, Plana F, Ruiz CR (2002) Source apportionment analysis of atmospheric particulates in an industrialized urban site in southwestern Spain. Atmos Environ 36:3113-3125. doi:10.1016/S1352-2310(02) 00257-1

Salam A, Bauer H, Kassin K, Ullah SM, Puxbaum H (2003) Aerosol chemical characteristics of a mega-city in Southeast Asia (Dhaka, Bangladesh). Atmos Environ 37:2517-2528. doi:10.1016/ S1352-2310(03)00135-3

Sharma M, Maloo S (2005) Assessment of ambient air $\mathrm{PM}_{10}$ and $\mathrm{PM}_{2.5}$ and characterization of $\mathrm{PM}_{10}$ in the city of Kanpur, India. Atmos Environ 39:6015-6026. doi:10.1016/j.atmosenv. 2005.04.041

Sharma VK, Patil RS (1992) Chemical composition and source identification of Bombay aerosol. Environ Technol 13:10431052

Smith DJT, Harrision RM, Luhana L, Casimiro AP, Castro LM, Tariq $\mathrm{MN}$ et al (1996) Concentrations of particulate airborne polycyclic aromatic hydrocarbons and metals collected in Lahore, Pakistan. Atmos Environ 30:4031-4040. doi:10.1016/1352-2310(96) 00107-0

West PW, Gaeke GC (1956) Fixation of sulphur dioxide as sulfitomercurate III and subsequent colorimetric determination. Anal Chem 28:1816-1819. doi:10.1021/ac60120a005

World Health Organization (WHO) (1999) WHO air quality guidelines for Europe. WHO regional office for Europe, WHO Regional Publications, European Series, Copenhagen

World Health Organization (WHO) (2000) WHO air quality guidelines for Europe 2000, 2nd edn. WHO regional office for Europe, WHO Regional Publications, European Series, Copenhagen

World Health Organization (WHO) (2005) WHO air quality guideline update. Report of the working group meeting. WHO, Bonn, Germany 